\title{
MARKET TIMING AND CAPITAL STRUCTURE: EVIDENCE FOR DUTCH FIRMS*
}

\author{
BY \\ TIJS DE BIE** AND LEO DE HAAN**
}

\begin{abstract}
Summary
We examine market timing and its effects on capital structures for a sample of Dutch listed firms and a sub-sample of Dutch initial public offering (IPO) firms. The results yield evidence of market timing. Stock price run-ups increase the probabilities of equity and dual issues. Further, the effects of stock price run-ups on the choices between issuance of debt, equity or both are consistent with the predictions of the market timing hypothesis. However, in contrast to the existing evidence for US firms, we do not find persistent effects of market timing on capital structures of Dutch firms.
\end{abstract}

Key words: capital structure, market timing

JEL Code(s): C23, G32

\section{INTRODUCTION}

Baker and Wurgler (2002, hereafter BW) suggest a new theory of capital structure: the 'market timing theory of capital structure'. This theory states that the current capital structure is the cumulative outcome of past attempts to time the equity market. Market timing implies that firms issue new shares when perceived to be overvalued and that firms repurchase own shares when considered to be undervalued. Market timing issuing behaviour has been well established empirically by others already, ${ }^{1}$ but BW find evidence for the

* This paper has benefited from useful comments from two anonymous referees, Allard Bruinshoofd, Frank de Jong, Jeroen Ligterink, seminar participants at De Nederlandsche Bank, and discussions at the 6th ONS Analysis of Enterprise Microdata Conference (Cardiff, 2005).

** De Nederlandsche Bank, P.O. Box 98, 1000 AB Amsterdam, The Netherlands. e-mail: t.m.de.bie@dnb.nl; 1.de.haan@dnb.nl

1 Studies presenting evidence that seasoned equity offerings coincide with high market valuations are, for example, Taggart (1977), Marsh (1982), Asquith and Mullins (1986), Korajczyk et al. (1991), Jung et al. (1996), Hovakimian et al. (2001). Share repurchases with low market valuations are documented by Ikenberry et al. (1995), among others. Long-term underperformance following seasoned equity offerings, as indirect evidence of market timing, is reported by e.g. Loughran and Ritter (1995, 1997), Spiess and Affleck-Graves (1995), Eckbo et al. (2000); for recent evidence of long-term underperformance following Dutch IPOs, see Doeswijk et al. 
US that the influence of market timing on capital structure is highly persistent. This finding of persistency initiated studies testing the consequences of changes in equity market valuation on capital structure. Kayhan and Titman (2007; hereafter KT) elaborate on BW's market timing measure and confirm that leverage changes are driven by market-timing. However, in contrast to BW, they do not confirm the long-term persistency of market timing effects. Hovakimian, Hovakimian and Tehranian (2004; hereafter HHT) investigate whether the issuance decisions of firms are consistent with market timing behaviour or traditional theories, notably trade-off and pecking order theories, and conclude that it is consistent with both the market timing and pecking order hypotheses.

To our knowledge, there are no studies for the Netherlands on the consequences of market timing for capital structures. This is the aim of this paper. We take the above-mentioned studies of BW, KT and HHT as our benchmark and use elements of the analytical methods applied by all these authors to test the robustness of our results.

All the studies for the US are dealing with the case of a highly marketoriented financial system, where corporate firms tap the public capital markets quite often. In this paper, we test the market timing hypothesis for the Netherlands where the financial system is less market oriented than in the US. Earlier studies show that Dutch firms have a relatively strong preference for internal finance over external finance. When firms need external finance, they prefer bank loans over the issuance of securities. When they go to the public capital market, shares are issued more frequently than bonds due to the relative underdevelopment of the corporate bond market in comparison to the stock market (De Haan and Hinloopen, 2003). The financial system in the Netherlands is characterized by a prominent role of banks in the financing of industry (Fase (2001), Saunders and Schmeits (2002)). Stock buy-backs are less frequently observed in the Netherlands than in the US, the more so in the period under consideration in the present study because of tax disadvantages at that time. In view of these characteristics we expect that Dutch firms, in comparison to US firms, are less inclined to time the equity market. We use a sample of Dutch non-financial listed firms to examine this. To facilitate comparison with the US and as a robustness check, we apply several methods of analysis used in a number of studies for the US on our sample of Dutch firms.

The paper proceeds as follows. After a brief review of the theory in section 2 , section 3 describes the data. Then sections 4 and 5 present the results of applying several of the methods of analyzing the market timing hypothesis

(2006). Another evidence for market timing is the survey by Graham and Harvey (2001) in which CFOs admit that the market value of the stock (and the recent price run-up) is an important consideration for the timing of equity issues. 
TABLE 1 - HOW MARKET PERFORMANCE AFFECTS CORPORATE FINANCING: SUMMARY OF THE HYPOTHESES

\begin{tabular}{|c|c|c|c|c|}
\hline \multirow[t]{2}{*}{ Financing decision } & \multirow{2}{*}{ Market performance variable } & \multicolumn{3}{|c|}{ Hypothesis } \\
\hline & & Trade-off & Pecking order & Market timing \\
\hline \multirow[t]{2}{*}{ a. Leverage } & Market-to-book ratio & - & - & - \\
\hline & Stock return & - & - & - \\
\hline \multirow[t]{2}{*}{ b. Debt vs. equity issue } & Market-to-book ratio & - & - & - \\
\hline & Stock return & $+{ }^{a}$ & - & - \\
\hline \multirow[t]{2}{*}{ c. Dual vs. equity issue } & Market-to-book ratio & - & 0 & 0 \\
\hline & Stock return & $+a$ & 0 & 0 \\
\hline \multirow[t]{2}{*}{ d. Debt vs. dual issue } & Market-to-book ratio & - & - & - \\
\hline & Stock return & $+a$ & - & - \\
\hline
\end{tabular}

$+, 0,-$ denote positive effect, no effect, negative effect, respectively. Source: Hovakimian et al. (2004), unless stated otherwise.

a Authors' interpretation, see main text.

on our sample of Dutch firms. More specifically, section 4 searches for effects of market timing on capital structure, section 5 for evidence of market timing in firms' issuance behaviour. Section 6 concludes.

\section{CAPITAL STRUCTURE THEORY AND STOCK MARKET PERFORMANCE}

Not only the market timing theory, but also the - more traditional - tradeoff and the pecking order theories have something to say about the effect of stock market performance on capital structure decisions. In this section we give a short account of the major hypotheses of the static trade-off theory, the pecking order theory, and the market timing theory, particularly dealing with the effects of stock market performance on corporate financing decisions. ${ }^{2} \mathrm{We}$ thereby discuss two aspects of corporate financing decisions: (1) those concerning firms' capital structures and (2) what to issue at a particular point in time: equity, debt, or both (the latter is called a 'dual issue'). The predictions are summarized in Table 1.

\subsection{Static Trade-off}

According to the static trade-off theory, firms have a target debt ratio, which is determined by balancing the cost and benefits of debt versus equity. Myers (1977) shows that one of the costs of debt is that excessively levered firms will more often have to pass up valuable investment projects. Therefore, firms with 
valuable growth opportunities should set lower target debt ratios. Given that a high market-to-book ratio is often associated with good growth opportunities, the trade-off theory predicts that firms with high market-to-book ratios will issue equity rather than debt and will have lower observed debt ratios.

Sometimes market performance is measured by stock returns. Especially when the stock return is the log return of the stock price over just one year, it is our interpretation of the trade-off theory that the stock return has a positive (and not a negative) effect on target leverage and the debt versus equity choice. Our reasoning goes as follows. A stock price run-up mechanically drives down debt ratios in market value terms, as the market value of equity increases with the stock price. This may result in a debt ratio that is lower than the target. Under the static trade-off theory, firms will then try to bring their debt ratios back towards target levels. One way to accomplish this is by issuing debt rather than equity. Hence, the trade-off theory predicts that stock returns have a positive effect on the debt versus equity issue choice.

Firms may also issue debt and equity at the same time instead of one at a time. Given that such dual issues include both debt and equity, they are less leverage-increasing than debt issues but are more leverage-increasing than equity issues. Therefore, the predicted signs for the effects for both the debt versus dual and the dual versus equity issuance choices are identical to the debt versus equity issuance choice.

\subsection{Pecking Order}

According to the pecking order hypothesis (Myers and Majluf (1984)), firms' financing choices are driven by the costs of adverse selection that arise as a result of information asymmetry between better-informed managers and lessinformed investors. These costs are incurred when firms issue securities, and are especially high for shares. As a result, firms issue equity as a last resort. According to the (dynamic version of the) pecking order hypothesis (Lucas and McDonald (1990)) firms issue equity following periods of high market performance. This version of the pecking order theory coincides to a large degree with the market timing theory. Indeed, both the probability of a debt versus equity issue and the observed debt ratios are expected to decline with high market performance.

The probability of a dual versus equity issue is expected to be unaffected by market performance. The reasoning is that if there is market timing behaviour, both equity and dual issuers are expected to time the market by issuing in periods of high market performance, and therefore market timing effects should be insignificant in this case.

The prediction that firms issue equity when their market performance is high applies to dual issues as well, because dual issues are defined as issues of both debt and equity. Debt issuers' market performance, on the other hand, 
is expected to be relatively low. As a result, pecking order financing would cause the probability of a debt versus dual issue to decline with market performance.

\subsection{Market Timing}

The market timing hypothesis states - as mentioned in the introduction - that firms time equity issuance to periods of high market performance. The underlying reasons for this timing behaviour could be related to the costs of adverse selection as in the pecking order or to some other phenomenon. The predictions of the market timing hypothesis regarding the effects of market performance on corporate financing coincide with the predictions of the pecking order hypothesis.

\section{DATA}

We use data from financial statements of Dutch companies that were listed on the Amsterdam Stock Exchange (AEX) during part or all of the period 1983 to 1997. Data are taken from the Yearbook of Dutch Companies. ${ }^{3}$ We select non-financial companies for which at least eight consecutive years of annual account data are available. This leaves us with an unbalanced panel of 135 companies, making out 86 per cent of the total balance sheet of all non-financial listed companies.

Following BW, we use two samples: one full sample and one IPO sub-sample consisting of firms that did an initial public offering (IPO). This facilitates exploitation of any distinctive characteristics of firms that have just gone public. It is conceivable that financing decisions are made differently by a firm which has already been publicly listed for a long time than by a firm which has just done an initial public offering. For each IPO-firm the first observation in the dataset is the year of its initial public offering. To be included in the IPO sub-sample a firm's IPO year should be identifiable, be equal to or greater than 1983 (being the first year in the dataset), and be followed by at least eight consecutive years of annual accounts data. Dates for initial public offerings are identified from the Amsterdam Exchange's annual reports and other sources. ${ }^{4}$ This results in an IPO-sample of 37 companies.

The definitions of the variables follow as closely as possible the definitions used in the US studies of CompuStat data such as BW and KT. Due to differences in accounting standards between the US and the Netherlands,

3 Original title in Dutch: 'Jaarboek van Nederlandse Ondernemingen.' Due to breaks and discontinuities in the entries for equity capital we can not use more recent data.

4 Additional information on initial public offerings is taken from IPO-lists provided by Euronext Amsterdam. 
TABLE 2 - SUMMARY STATISTICS

\begin{tabular}{|c|c|c|c|c|c|c|}
\hline & \multicolumn{2}{|c|}{ All firms } & \multicolumn{2}{|c|}{ IPO firms } & \multicolumn{2}{|c|}{ Non-IPO firms } \\
\hline & Median & Mean & Median & Mean & Median & Mean \\
\hline Firm size & 13.0 & 13.1 & $12.5^{* *}$ & $12.6^{* *}$ & 13.3 & 13.3 \\
\hline Tangibility & 0.347 & 0.358 & $0.296 * *$ & $0.306^{* *}$ & 0.369 & 0.386 \\
\hline Stock return & 0.110 & 0.181 & 0.096 & 0.157 & 0.121 & 0.192 \\
\hline Profitability & 0.087 & 0.088 & $0.105^{* *}$ & $0.108 * *$ & 0.077 & 0.077 \\
\hline Book leverage & 0.602 & 0.595 & $0.588^{*}$ & $0.586^{*}$ & 0.609 & 0.600 \\
\hline Market leverage & 0.481 & 0.491 & $0.421 * *$ & $0.436 * *$ & 0.520 & 0.520 \\
\hline Debt issues & 0.021 & 0.029 & $0.034 * *$ & 0.034 & 0.017 & 0.026 \\
\hline Equity issues & 0.000 & 0.012 & 0.000 & $0.019 * *$ & 0.000 & 0.009 \\
\hline Market-to-book ratio & 1.157 & 1.336 & $1.274 * *$ & $1.542 * *$ & 1.101 & 1.225 \\
\hline Number of firm-year observations & 1781 & 1781 & 624 & 624 & 1157 & 1157 \\
\hline
\end{tabular}

Explanatory note: Medians (means) for IPO firms are marked * and ** respectively when significantly different from medians (means) for non-IPO firms at the $5 \%$ and $1 \%$ level. The reported significance levels for medians are based on the Pearson chi-square test while the levels for means are based on the $t$-test. Variable definitions are given in Appendix A.

some corrections have been made in the Dutch balance sheet data in order to construct comparable debt ratios. ${ }^{5}$ The Dutch annual reports of firms specify provision items on the liabilities side of the balance sheet that do not exist in the US. Therefore, pension provisions and revaluation provisions are excluded when calculating debt ratios. In doing so we avoid that the sometimes severe yearly fluctuations in the revaluation provisions affect leverage ratios.

Table 2 gives summary statistics for our sample of firms, IPO firms and non-IPO firms, respectively. The main differences between IPO firms and nonIPO firms is that IPO firms are smaller in size, have lower tangibility, are more profitable, have lower leverage - especially in market terms - and have a higher market-to-book ratio. Taking market-to-book ratios as a proxy for growth opportunities, this suggests that IPO-firms have above average growth opportunities. This is also what could be expected. Firms applying for an initial listing on the stock exchange are often doing so because they need large amounts of funds for their investment plans. Issuing activity is also somewhat higher for IPO firms.

The higher issuing activity of IPO firms is correlated with stock market performance. This is illustrated by Figure 1, which shows net flows of debt and equity issues as a percentage of total assets, classified according to stock returns. We first sort firms by year (to control for macroeconomic issuing 

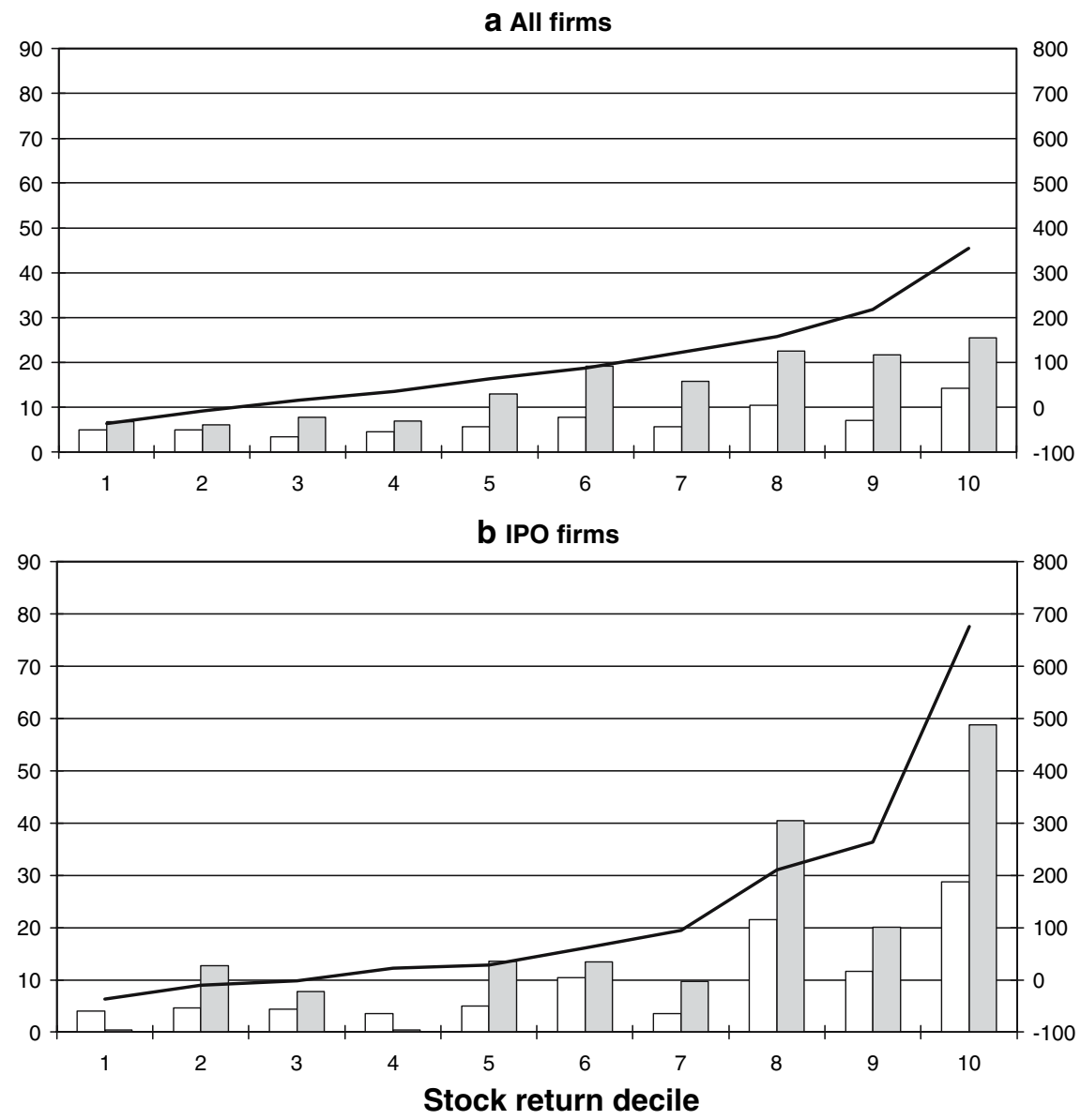

Equity (left axis) $\square$ Debt (left axis) — Stock return (right axis)

Figure 1 - Net debt and equity issues, classified by stock returns (five-year periods) Explanatory note: Variable definitions are given in Appendix A. However, note that the figures are now in percentages. All numbers represent medians. Firms are sorted first by year (to control for macroeconomic issuing trends), then by sales (to control for firm size), and then allocated to deciles on the basis of their stock return rank (within each group of 10 consecutive firms).

trends) and then by sales (to control for firm size) and, within each consecutive set of ten (similarly sized) firms, allocate them into ten deciles on the basis of their stock return performance. This procedure keeps a roughly equal number of firms in each decile and maximizes the spread in stock returns 
across deciles, holding calendar year and firm size constant. ${ }^{6}$ The figure gives medians for a 5-year period.

For all firms we find that equity issues rise with stock returns. However, equity issues are smaller than debt issues, which rise with stock returns as well. For IPO-firms the pattern for debt and equity issues is irregular and therefore more difficult to interpret. We conclude that stock price run-ups not only prompt firms to issue more equity but also to issue more debt, and the latter in larger quantities than the former. This pattern for debt issues differs from Welch (2004), who finds more debt issues with poor stock market performance for US firms. This suggests that debt and equity are more substitutable in the US than in the Netherlands. We will investigate the effect of stock market performance on the issuance of debt and/or equity further in section 5. But first, we deal with the effect of market timing on leverage in the next section.

\section{DOES MARKET TIMING AFFECT CAPITAL STRUCTURES OF DUTCH FIRMS?}

In this section we investigate the effects of market timing on leverage for our sample of Dutch firms. We show the results for the methodologies of BW and KT, respectively.

\subsection{External-finance-weighted Average Market-to-book Ratio}

BW provide evidence that equity market timing has a persistent effect on the capital structure of US firms. They find that leverage is strongly and negatively related to their market timing measure and conclude that the capital structure of a firm is the cumulative outcome of past attempts to time the equity market. Their measure for market timing, the so-called external-finance-weighted average market-to-book ratio $(E F W A M B)$, is defined as follows:

$$
E F W A M B_{t}=\sum_{s=1}^{t-1} \frac{e_{s}+d_{s}}{\sum_{r=1}^{t-1} e_{r}+d_{r}} \times(M / B)_{s}
$$

where $e$ and $d$ denote equity and debt issues, respectively, $M / B$ is the marketto-book ratio, and suffix $s$ and $r$ denote time. For a firm observed at time $t$, the $E F W A M B$ is the weighted average of a time-series of past market-to-book ratios, starting with year 1 , i.e. the first observation available in our sample, and ending with the market-to-book ratio at $t-1$ (for IPO firms year 1 is the first year the IPO firm is listed on the stock exchange). The weight for each

6 The classification procedure follows Welch (2004). 
year is the ratio of external financing in that year to the total external financing raised by the firm in years 1 through $t-1$. Thus, firms that issue a lot of equity when market-to-book ratios are relatively high will tend to have high values of $E F W A M B$. However, we note that the same holds for firms that issue a lot of debt when market valuation is high. Equity issues are defined as the change in the book value of share capital including the share premium reserve, debt issues as the change in the book value of debt. As in BW, negative weights $\left(\left(e_{s}+d_{s}\right) / \sum\left(e_{r}+d_{r}\right)\right)$ are reset to zero.

Following BW, we regress leverage on EFWAMB plus the usual Rajan and Zingales (1995) set of control variables including the unweighted market-tobook, tangibility, profitability and firm size. ${ }^{7}$ The unweighted market-to-book ratio controls for 'the cross-sectional variation in the level of market-to-book. What is left for $E F W A M B$ is the residual influence of past, within-firm variation in market-to-book' (BW, p.15). The usual assumption is that larger and more tangible firms are safer debtors and therefore can get more debt. The effect of high profitability on leverage is negative according to the pecking order theory (more retained earnings), whereas it is positive according to the trade-off theory (higher tax savings from debt, lower probability of bankruptcy, potentially higher overinvestment).

The hypothesis is that if firms systematically time their equity issues to the market $E F W A M B$ should have a significantly negative effect on leverage. If firms do not systematically issue relatively more equity than debt when the level of market valuation is high, EFWAMB would be not significant. There may even be a significantly positive relationship if firms issue relatively more debt when stock markets are high. Table 3 presents the results. Panel A gives the results for all firms in our sample, panel B for IPO firms. As in BW, we present cross-section regressions for separate years as well as Fama-MacBeth regressions for the whole sample period ('All years'). ${ }^{8}$ The other rows give cross-section estimates for single years, with $E F W A M B$ running from the first year the firm appears in the sample (i.e. the IPO year for IPO-firms) until the year prior to the current year.

In contrast to BW's results for the US, we find coefficients for $E F W A M B$ that are mostly insignificant, especially when leverage is measured in book values. Hence, we conclude that a history of market timing, as summarized by BW's $E F W A M B$, does not, or does not as significantly and negatively, affect corporate leverage in the Netherlands as it does in the US.

7 Appendix A gives all variable definitions.

8 Fama-MacBeth coefficients are averages of the time series of the coefficients found in the annual cross-section regressions. This method eliminates the problem of serial correlation in the residuals of a time-series cross-sectional regression. All $t$-statistics are corrected for heteroskedasticity. 


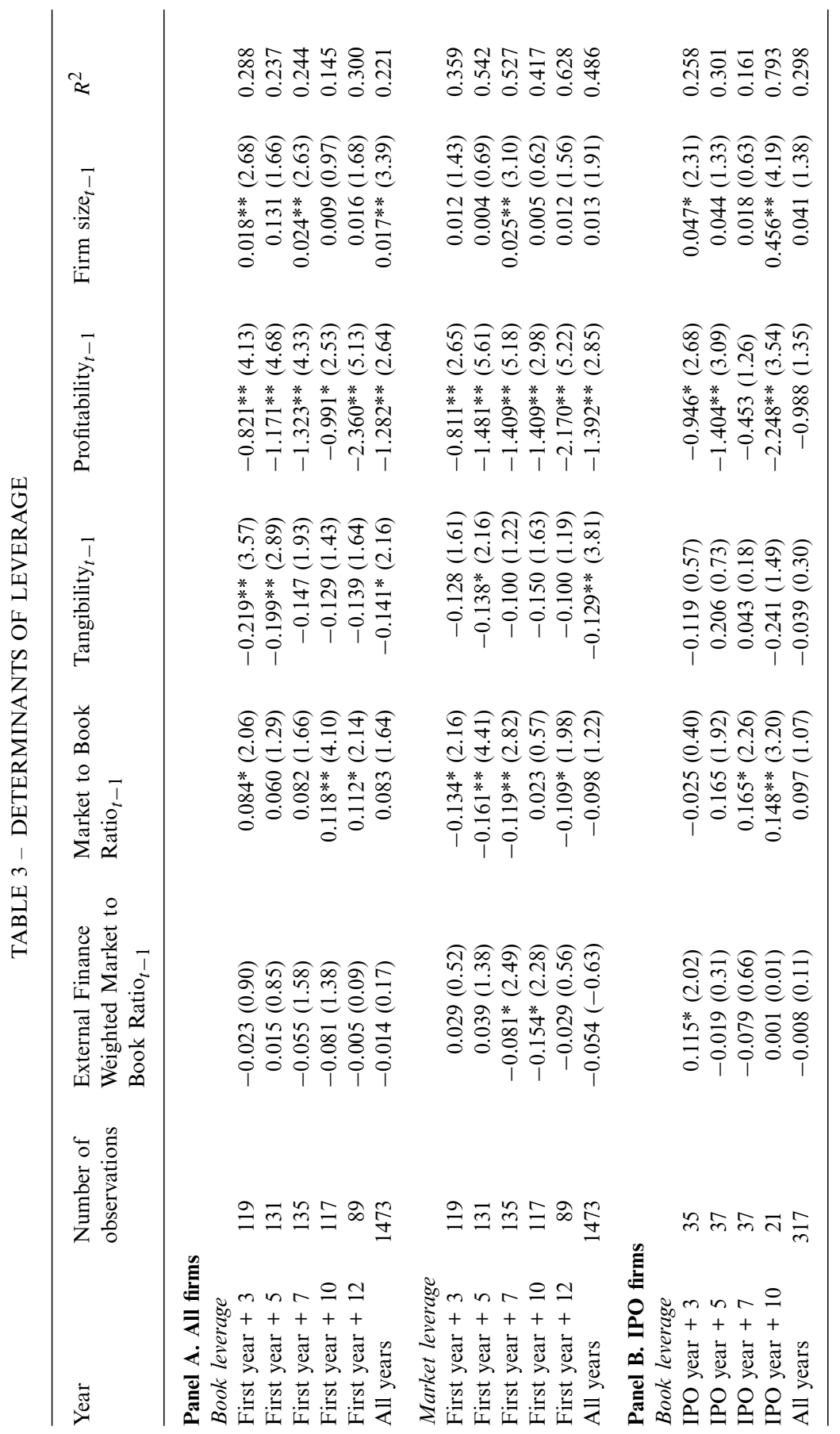




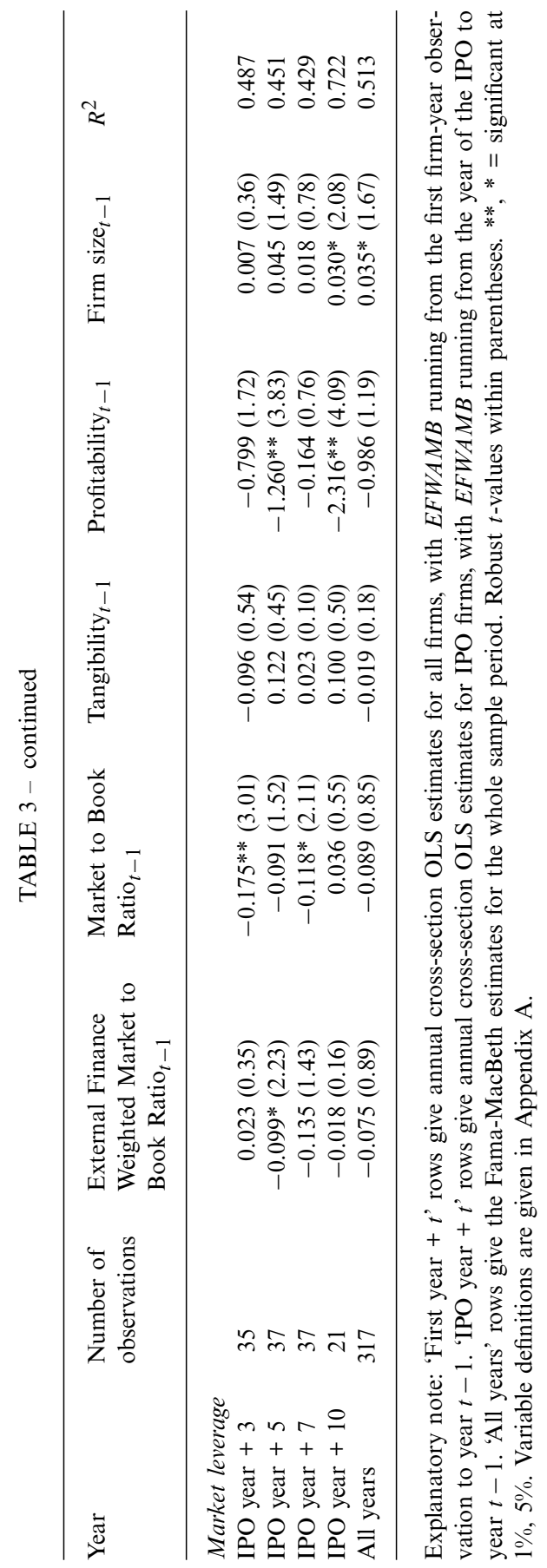


As for the control variables, we note a quite robust result, namely that the sign of the coefficient of the (unweighted) market-to-book ratio in the leverage equations is mostly positive when leverage is measured in book values, but switches into negative values when leverage is measured in market values. This outcome, which is also present in BW's results, indicates spurious correlation stemming from the fact that the market value of equity is both in the denominator of leverage in market value terms and in the numerator of the market-to-book ratio. This spurious correlation problem has been discussed already by Titman and Wessels (1988). We also estimated the equations leaving out market-to-book, but this did not improve the significance of $E F W A M B$. Among the other control variables, profitability seems most significant and robust to changes in sample period and definition of leverage. Its negative sign is in support of the pecking order prediction, that firms with high profits have lower debt ratios as they prefer to finance investment internally. Size has the expected positive sign (as large firms are assumed to enter less often financial distress) but is not always significant. Tangibility has a negative sign, mostly, though not always significant, which is unexpected as one would expect firms with more tangible assets and thus collateral value to borrow more easily than firms with lower tangibility. ${ }^{9}$

\subsection{Yearly Timing, Long-term Timing, Stock Price Run-up}

KT continue the line of research of BW and show that BW's EFWAMB measure can be split into two components:

$$
\begin{aligned}
E F W A M B_{t-1} & =\sum_{s=0}^{t-1} \frac{e_{s}+d_{s}}{\sum_{r=0}^{t-1} e_{r}+d_{r}} \times(M / B)_{s}=\frac{\operatorname{cov}(F D, M / B)}{\overline{F D}}+\overline{(M / B)} \\
& =\frac{Y T+L T}{\overline{F D}}
\end{aligned}
$$

where $F D \equiv(e+d)$, as defined above, and a bar above the variable denotes the average level over the period 0 to $t-1 \cdot \operatorname{Cov}(F D, M / B)$ is the covariance between external financing and market valuation. $Y T$ and $L T$ are the two components into which KT split EFWAMB and stand for 'Yearly Timing' and 'Long-term Timing', respectively. KT multiply (2) by $\overline{F D}$ to arrive at the Yearly Timing measure:

$$
Y T=\operatorname{cov}(F D, M / B)
$$

9 A negative correlation between collaterizability and leverage can be argued to exist by assuming that the bonding role of debt becomes more important when the firms' capital outlays are less collaterizable and thus more difficult to monitor by lenders, in particular banks. 
and the Long-term Timing measure:

$$
L T=(\overline{M / B}) \times(\overline{F D)}
$$

$Y T$ is KT's 'real' measure of market timing and (in line with BW's expectation for $E F W A M B$ ) is expected to be negatively related to leverage if firms issue relatively more equity than debt when stock market valuation is high. $L T$ is also expected to have a negative relationship with leverage, but KT point out that this may reflect factors unrelated to market timing. For example, as pointed out in section 2, firms that have high growth opportunities, and therefore high average market-to-book ratios, may choose not to finance with debt but with equity instead to maintain their financial flexibility (Myers, 1977). Hence, $L T$ may be considered to be a control variable for growth opportunities, like the unweighted market-to-book ratio in BW's model. ${ }^{10}$

KT include an additional market timing variable, the cumulative stock return, measured as the cumulative log return on the stock over the years $t-4$ till year $t$. The difference between $Y T$ and the stock return is that the former measures stock market valuation in levels while the latter measures it in terms of changes. The stock return is added to account for the direct impact of market timing behaviour on capital structure changes. The effect can take place in two ways. First, when leverage is measured in market values there is a direct and mechanical negative impact of stock prices on leverage. ${ }^{11}$ Moreover, if firms issue more equity than debt when there is a stock price run-up, whatever the market-to-book ratio, a negative relationship between leverage changes and stock returns is expected.

Following KT, the equation has been estimated using a Generalized Least Square regression (GLS) with random effects. In order to get consistent standard errors bootstrapping techniques are used (Efron (1979)). This corrects for biases resulting from using multiple observations and moving lagged variables. We draw 200 bootstrapped samples by repeated sampling, with replacement from the population. The sample drawn during each replication is a bootstrap sample of clusters, which preserves the time-series structure of the data. A cluster is formed by observations of one firm (it is assumed there is no cross-section correlation).

Table 4 gives the results. ${ }^{12}$ Although KT do not present results for IPO firms, we present the results for both the whole sample (Panel A) and the

10 We also re-estimated BW's model, replacing $E F W A M B$ by $Y T$ and $L T$. Again, the results were not significant.

11 Welch (2004) especially examines this relationship between stock price changes and market leverage ratios. He shows that firms do not counteract the effects of stock price changes on market leverage ratios. As a consequence, changes in stock prices are negatively and closely related to changes in market leverage ratios.

12 Experiments with alternative time period frames (i.e. past 3 or 5 years instead of 4) did not alter the main conclusions of the analysis. 
TABLE 4 - DEPENDENT VARIABLE: CHANGE IN LEVERAGE BETWEEN YEAR T AND T-4, IN BOOK AND MARKET VALUES

\begin{tabular}{lcccc}
\hline & Book leverage & & \multicolumn{2}{c}{ Market leverage } \\
\hline Panel A. All firms & & & & \\
& Coefficient & $t$-value & Coefficient & $t$-value \\
Yearly timing, past 4 years & 0.239 & 0.73 & 0.128 & 0.47 \\
Long-term timing, past 4 years & 0.010 & 0.06 & 0.047 & 0.39 \\
4-year cumulative stock return & $-0.010^{*}$ & 2.08 & $-0.067^{* *}$ & 7.03 \\
Deviation from target leverage, $t-4$ & $-0.464^{* *}$ & 10.98 & $-0.310^{* *}$ & 7.00 \\
4-year cumulative financial deficit & 0.079 & 1.11 & 0.102 & 1.55 \\
Idem, if positive financial deficit & 0.106 & 1.43 & 0.074 & 1.27 \\
4-year cumulative profitability & $-0.093^{* *}$ & 3.38 & $-0.068^{*}$ & 2.42 \\
Adj. $R^{2}$ & 0.399 & & 0.575 & \\
Number of observations & 1114 & & 1114 & \\
Number of clusters & 151 & & & 151 \\
Panel B. IPO firms & & & & \\
Yearly timing, past 4 years & -0.084 & 0.35 & -0.166 & 0.64 \\
Long-term timing, past 4 years & -0.038 & 0.14 & -0.157 & 0.81 \\
4-year cumulative stock return & -0.001 & 0.08 & $-0.048^{* *}$ & 3.45 \\
Deviation from target leverage, $t-4$ & $-0.449^{* *}$ & 4.82 & $-0.381^{* *}$ & 5.21 \\
4-year cumulative financial deficit & 0.046 & 0.46 & $0.222^{* *}$ & 3.27 \\
Idem, if positive financial deficit & 0.217 & 1.67 & 0.025 & 0.31 \\
4-year cumulative profitability & $-0.095^{*}$ & 2.17 & $-0.136^{* *}$ & 3.05 \\
Adj. $R^{2}$ & 0.390 & & 0.578 & \\
Number of observations & 260 & & 260 & \\
Number of clusters & 57 & & 57 & \\
\hline
\end{tabular}

Explanatory note: GLS regressions with random effects. The statistics for the industry dummies are suppressed. The $t$-statistics are obtained from 200 bootstrap replications resampled from the actual dataset with replacement of clusters. Observations that belong to the same firm form a cluster. $* *, *=$ significant at $1 \%, 5 \%$. Variable definitions are given in Appendix A.

sub-sample of IPO firms (Panel B). In this way we facilitate comparison with the BW results for leverage. The variable to be explained is the cumulative change of leverage over four years, in book terms and in market terms respectively (first and second column in the table). Our principle focus is on the timing variables, $Y T$ and the stock return. As usual, a set of control variables is added to account for other factors, which is similar to KT's. The first control variable is the deviation of actual leverage from target leverage. ${ }^{13}$ Second, a financial deficit measure and profitability are added to control for pecking order behaviour. As a financial deficit may have a different effect on leverage

13 Appendix B presents the first pass regression to determine the deviation from the target capital structure. 
TABLE 5 - SAMPLE DISTRIBUTION

\begin{tabular}{lccc}
\hline Year & Equity issue & Debt issue & Dual issue \\
\hline 1984 & 11 & 13 & 0 \\
1985 & 11 & 21 & 0 \\
1986 & 25 & 27 & 5 \\
1987 & 12 & 28 & 2 \\
1988 & 8 & 41 & 4 \\
1989 & 21 & 35 & 6 \\
1990 & 10 & 41 & 6 \\
1991 & 7 & 45 & 3 \\
1992 & 6 & 29 & 1 \\
1993 & 11 & 21 & 3 \\
1994 & 11 & 19 & 4 \\
1995 & 13 & 24 & 12 \\
1996 & 20 & 28 & 5 \\
1997 & 13 & 35 & 51 \\
Total & 179 & 407 & \\
\hline
\end{tabular}

Explanatory note: Variable definitions are given in Appendix A.

than a financial surplus, financial deficit is also included in the model interacted with a dummy variable which takes the value of 1 when the financial deficit is positive and zero otherwise.

The results of the estimation appear to be similar for the whole sample of firms and the sub-sample of IPO-firms. Therefore we discuss them together. We find a significantly negative coefficient for the stock return, which is greater and more significant when leverage is measured in market values. As mentioned above, this relationship is partly mechanical for market leverage, although the small effect on book leverage found for the whole sample (but not for IPO firms) indicates that firms use relatively more equity after periods of a stock price increase, which would be in accordance with market timing. This outcome would also be consistent with the empirical evidence of KT for the US and earlier evidence for the Netherlands. Both De Jong en Veld (2001) and De Haan and Hinloopen (2003) find evidence that Dutch firms issue more equity after a stock price run-up. Hence, there is some evidence of a short-term effect of market timing on leverage related to the stock return. However, the market-to-book based timing measure $Y T$ is not found to be significant. This implies that the market timing behaviour of Dutch firms addresses changes rather than levels of stock market valuation.

\section{DO DUTCH FIRMS TIME THEIR ISSUES TO THE MARKET?}

In this section the focus shifts from capital structure to issuance behaviour. Specifically, we look at the decision to issue equity, debt, both, or not to issue, 
and ask ourselves whether the timing of these decisions is consistent with the market timing hypothesis that predicts that firms will issue equity more often when market performance is high. Table 5 gives the number of equity issues, debt issues and dual issues in our sample. A dual issue occurs when a firm issues debt and equity at the same time (i.e., in our sample within the same year). For equity issues we use the issuance book of the Amsterdam stock exchange. ${ }^{14}$ For debt issues we count debt issues that raise the book value of long-term debt plus short-term bank debt by more than $5 \%$ of total assets; we use this threshold since the focus is on significant issues. ${ }^{15}$ The relative frequencies are comparable to the US sample of HHT. Debt issues are most frequent in their sample as well as in ours, equity issues come second, and dual issues third (dual issues make out $8 \%$ of all issues in our sample against $12 \%$ in HHT's). To preserve a sufficient number of observations in the following analysis of relatively infrequent equity and dual issues, we will no longer present separate results for IPO-firms. ${ }^{16}$

First, we present some direct observations on issuance decisions. Then we present a probit analysis, like HHT.

\subsection{Direct Observations on Issue Decisions}

One way to directly observe market timing is by looking at changes in market-to-book or stock prices in or around the year of an event such as an equity issue. The idea is that if it is found that market-to-book is often relatively high just before an equity issue, this would suggest market timing of equity issues.

Panel A of Table 6 shows changes in market-to-book ratios around the issue years. We give the three year period before and after the issue, to be able to check whether the change before the issue is different to the change afterwards. It appears that, indeed, equity issues occur after a significant increase of the market-to-book ratio, by 9.2 percentage points at the median, which is not continued afterwards. Also debt issues follow an increase of the market-to-book ratio. Dual issues of debt and equity take place after a significant increase of the market-to-book ratio as well. Panel B shows that equity, debt and dual issues all follow after a period of stock price rises. During the

14 For the issuance analysis we prefer this source over firms' balance sheets to determine the incidence of equity issuance.

15 This five percent screen has also been used by Hovakimian (2006) and previous studies (e.g. Hovakimian et al. (2001), De Haan and Hinloopen (2003)). Results are not very sensitive for variations in this threshold from $2.5 \%$ to $7.5 \%$.

16 The results in the previous section show that these firms do not behave very differently from the average firm in our dataset. Moreover, apart from BW, none of the other benchmark studies consider IPO-firms. 
TABLE 6 - CHANGES IN MARKET PERFORMANCE VARIABLES AROUND ISSUE DECISIONS

\begin{tabular}{|c|c|c|c|c|c|c|}
\hline & \multicolumn{2}{|c|}{$(M / B)_{t-1}-(M / B)_{t-3}$} & & \multicolumn{2}{|c|}{$(M / B)_{t+3}-(M / B)_{t}$} & \\
\hline \multicolumn{7}{|c|}{ Panel A. Changes in market-to-book ratios $(M / B)$ around the year of issuance } \\
\hline & Median & Mean & Obs. & Median & Mean & Obs. \\
\hline Equity issue & $0.092^{* *}$ & $0.149 * *$ & 122 & -0.002 & -0.097 & 116 \\
\hline Debt issue & $0.031^{* *}$ & 0.040 & 319 & 0.012 & 0.016 & 281 \\
\hline Dual issue & $0.086^{*}$ & 0.139 & 42 & -0.014 & -0.110 & 23 \\
\hline & \multicolumn{3}{|c|}{$\begin{array}{l}\left(\text { Stock price }_{t-1}-\text { Stock }\right. \\
\left.\text { price }_{t-3}\right) / \text { Stock price }_{t-3}\end{array}$} & \multicolumn{2}{|c|}{$\begin{array}{l}\left(\text { Stock price }_{t+3}-\text { Stock }\right. \\
\left.\text { price }_{t}\right) / \text { Stock price }_{t}\end{array}$} & \\
\hline \multicolumn{7}{|c|}{ Panel B. Changes in stock prices around the year of issuance } \\
\hline & Median & Mean & Obs. & Median & Mean & Obs. \\
\hline Equity issue & $0.322 * *$ & $0.660^{* *}$ & 122 & 0.043 & $0.194 *$ & 116 \\
\hline Debt issue & $0.259^{* *}$ & $0.514 * *$ & 319 & $0.075^{* *}$ & $0.247^{* *}$ & 281 \\
\hline Dual issue & $0.401^{* *}$ & $0.940 * *$ & 42 & -0.093 & 0.051 & 23 \\
\hline
\end{tabular}

Explanatory note: Changes significantly different from zero at $5 \%$ and $1 \%$ level are marked $*$ and ** respectively. The reported significance levels for medians are based on the Wilcoxon signed rank test while the levels for means are based on the $t$-test. Variable definitions are given in Appendix A.

3 years after debt and equity issues, stock prices show a significant increase as well, but this increase is smaller in magnitude than before the issue.

These direct observations indicate that not only equity but also debt is issued when stock performance is high. A similar observation was already made above when discussing Figure 1. Of course, Table 6 only gives a partial analysis of debt and equity issuing decisions. Therefore, in the following subsection we present a more comprehensive analysis of issuance behaviour, incorporating market timing behaviour.

\subsection{Probit Analysis of Debt and Equity Issues}

In this subsection we perform a probit analysis to model the probabilities of an equity, debt or dual issue as a function of market performance variables plus a set of control variables. In this we follow the approach for US firms taken by HHT.

We use similar explanatory variables as HHT. Our main focus is, naturally, on the market timing variables, i.e. the market-to-book ratio and the stock return. Most of the control variables used by HHT are taken from Rajan and Zingales (1995) and have already been introduced. Among the new variables are a book value dilution dummy, selling expenses, industry leverage, and issue size. The book value dilution dummy is set equal to one when the firm's 


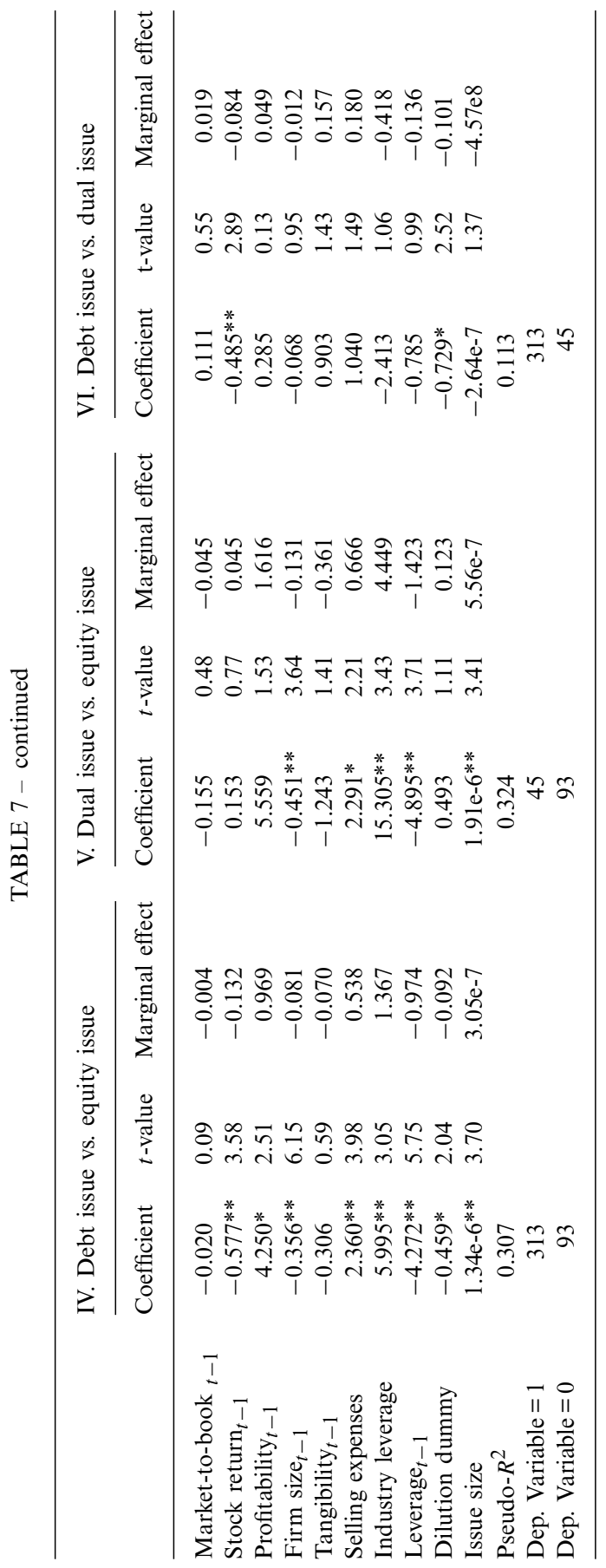


market-to-book ratio is greater than one $(M / B>1)$. HHT include this variable because managers appear to be reluctant to issue equity if it dilutes the accounting measures of performance or value. Firms with unique assets and products (proxied by high selling expenses) may have relatively high bankruptcy costs and, therefore, low leverage targets. Industry median debt ratios are added to mitigate the problem of omitted variables. Issue size is added to control for the possibility that firms not only time the event of issuance but also the amount issued.

Columns I to III of Table 7 give the estimates for the choice to issue versus not to issue. We focus on the market performance variables. Market-to-book is not found to be significant in any of the regressions. However, the stock return has a significantly positive effect on the issuance of equity as well as on dual issues. This indicates market timing of equity issues and dual issues. Hence, debt issues are timed to the market if they go along with equity issues. Firms do not time debt issues without timing equity issues as well. Thus, we find evidence of market timing, in the sense that equity issues and dual issues follow stock price run-ups. So again we observe that a high market performance prompts firms to issue not only equity, but also debt at the same time. This may also be the explanation of our finding that neither $E F W A M B$ nor $Y T$ significantly and negatively affects leverage for our sample of firms.

Columns IV to VI of Table 7 give the results for the choice to issue debt, equity, or both. We again focus on the estimates for the coefficients of market-to-book and stock return. HHT point out that especially the signs of these coefficients may provide discriminating evidence on the validity of the competing hypotheses: the trade-off theory on the one hand and the market timing and pecking order theory on the other. The relevant theoretical expectations have been discussed in Section 2 and summarized in Table 1.

The evidence in columns IV to VI is consistent with the predictions of the pecking order and market timing hypotheses as far as it concerns the effects of stock returns on the choice to issue equity, debt or both. The coefficient of the stock return is significantly negative in the debt versus equity issue choice and in the debt versus dual issue choice, and it is not significantly different from zero in the dual versus equity issue choice. These results are inconsistent with the trade-off theory. Market-to-book is significant in none of the regressions.

\section{CONCLUSION}

In this paper we examine market timing and its effects on capital structures for a sample of Dutch firms. We examine both a full sample and a sub-sample of IPO firms and use several methods of analysis from the recent US literature. The results are quite robust to the sample and methodology employed. 
First, we find evidence of market timing by Dutch firms. Stock price runups lead to lower leverage and increase the probability that a firm issues equity. A noteworthy observation is that stock price run-ups also increase the probability of a dual issue. Further, the effects of stock price run-ups on the choices between issuance of debt, equity or both are consistent with the predictions of the market timing (and pecking order) hypotheses and inconsistent with the trade-off theory.

Second, however, in contrast to the findings for the US, we do not find persistent effects of market timing on capital structures for our sample of Dutch firms. Alternative specifications of market timing measures do not significantly change this result.

\section{APPENDIX A - DEFINITION OF VARIABLES}

Variable name, symbol

(alphabetical order)

Book leverage

Debt issue (Section 5)

Debt issues ( $d$, Section 4)

Deviation from target leverage

Dilution dummy

Dual issue (Section 5)

Equity issue (Section 5)

Equity issues (e, Section 4)

External-finance-weighted

Market-to-book ratio (EFWAMB)

Financial deficit $(F D)$

\section{Definition}

Total debt / Total assets

If the change in the book value of long-term debt plus short-term bank debt in one year is greater than $5 \%$ of total assets

Change in book value of total debt / Total assets

Residual from regression in Appendix B

If Market-to-Book > 1

Coincidence of equity and debt issue in one year

If share issue(s) take(s) place in a year according to the issue data of Amsterdam Stock Exchange

(Number of shares $_{t} \times$ Stock price $_{t}-$ Number of shares ${ }_{t-1} \times$ Stock price $_{t}$ ) / Total assets $t$

See formula of EFWAMB in main text

Change of sum of book value of share capital including share premium reserve and book value of debt 
Variable name, symbol

(alphabetical order)

\section{Firm size}

Industry leverage

Issue size

Long-term timing ( $L T)$

Market leverage

Market-to-book ratio $(M / B)$

Profitability

Selling expenses

Stock return

Tangibility

Target leverage

Yearly timing $(Y T)$

\section{Definition}

\section{Logarithm of total turnover}

Median of book leverage in two-digit SIC industry to which a firm belongs Change of sum of book value of longterm debt, short-term bank debt and amount of equity issues according to Amsterdam Stock Exchange

See formula of $L T$ in main text

(Book value of total debt) / (Balance sheet total-Book value of equity + Number of stocks $\times$ Stock price)

(Balance sheet total-Book value of equity + Number of stocks $\times$ Stock price)/Balance sheet total

Earnings before interest and taxes /

Total assets

Cost of goods sold

First difference of the logarithm of the stock price

Physical assets / Total assets

Prediction from regression in Appendix B

See formula for $Y T$ in main text

\section{APPENDIX B - ESTIMATING TARGET LEVERAGE}

The target leverage is approximated by regressing leverage on a set of firmspecific variables and using the residuals from this regression as deviations from the target capital structure. ${ }^{17}$ The four variables used as determinants in these regressions are the usual Rajan and Zingales (1995) ones: firm size, asset tangibility, market-to-book ratio and profitability. Industry dummies have also been included to account for industry-specific effects. The table gives information on the distribution of the residuals that are used as deviations from target leverage.

17 This is a common procedure in the capital structure literature, which is not only used by Kayhan and Titman (2007) but also by e.g. Hovakimian et al. (2001), De Jong en Veld (2001), De Haan and Hinloopen (2003), among others. 
TABLE B.1 - PREDICTING TARGET LEVERAGE (TOBIT REGRESSIONS)

\begin{tabular}{lcccc}
\hline & \multicolumn{2}{l}{ Book leverage } & \multicolumn{2}{l}{ Market leverage } \\
\cline { 2 - 5 } & Coefficient & $t$-value & Coefficient & $t$-value \\
\hline Market-to-book ratio $_{t-1}$ & $0.079^{* *}$ & 11.05 & $-0.092^{* *}$ & 12.09 \\
Tangibility $_{t-1}$ & -0.016 & 0.76 & 0.012 & 0.52 \\
Profitability $t-1$ & $-0.992^{* *}$ & 16.43 & $-1.029^{* *}$ & 16.03 \\
Firm size $_{t-1}$ & $0.014^{* *}$ & 7.62 & $0.009^{* *}$ & 4.55 \\
Number of observations & 1737 & & 1736 & \\
Likelihood & 516.15 & & 1154.99 & \\
$p$-value & 0.000 & & 0.000 & \\
& Median & Std. dev. & Median & Std. dev. \\
Deviation from target leverage & -0.005 & 0.132 & 0.008 & 0.141 \\
Predicted target leverage & 0.604 & 0.078 & 0.513 & 0.137 \\
\hline
\end{tabular}

Explanatory note: The statistics for the industry dummies are suppressed. ${ }^{* *}, *=$ significant at $1 \%, 5 \%$. Variable definitions are given in Appendix A.

\section{REFERENCES}

Asquith, P. and D.W. Mullins (1986), 'Equity Issues and Offering Dilution,' Journal of Financial Economics, 15, pp. 61-89.

Baker, M. and J. Wurgler (2002), 'Market Timing and Capital Structure,' Journal of Finance, 57(1), pp. 1-32.

De Haan, L. and J. Hinloopen (2003), 'Preference Hierarchies for Internal Finance, Bank Loans, Bond, and Share Issues: Evidence for Dutch firms,' Journal of Empirical Finance, 10, pp. 661-681.

De Jong, A. and C. Veld (2001), 'An Empirical Analysis of Incremental Capital Structure Decisions Under Managerial Entrenchment,' Journal of Banking \& Finance, 25, pp. 1857-1895.

Doeswijk, R.Q., H.S.K. Hemmes and R.H. Venekamp (2006), '25 Years of Dutch IPOs: An Examination of Frequently Cited IPO Anomalies within Main Sectors and During Hot- and Cold-issue Periods', De Economist, 154, pp. 154-405.

Eckbo, E., R. Masulis, and O. Norli (2000), 'Seasoned Public Offerings: Resolution of the 'New issues puzzle', Journal of Financial Economics, 56, pp. 251-291.

Efron, B. (1979), 'Bootstrap Methods, Another Look at the Jackknife,'Annals of Statistics, 7, pp. $1-26$.

Fase, M.M.G. (2001), 'Financial Intermediation and Long-run Economic Growth in the Netherlands Between 1900 and 2000', in: H. Klok, T. van Schaik and S. Smulders (eds.), Economologues, Tilburg, Tilburg University, pp. 85-98.

Graham, J.R. and C.R. Harvey (2001), 'The Theory and Practice of Corporate Finance: Evidence from the Field,' Journal of Financial Economics, 60, pp. 187-243.

Hovakimian, A. (2006), 'Are Observed Capital Structures Determined by Equity Market Timing?, Journal of Financial and Quantitative Analysis, 41(1), pp. 221-243. 
Hovakimian, A., T. Opler and S. Titman (2001), 'The Debt-Equity Choice,' Journal of Financial and Quantitative Analysis, 36, pp. 1-24.

Hovakimian, A., G. Hovakimian and H. Tehranian (2004), 'Determinants of Target Capital Structure: The Case of Dual Debt and Equity Issues,' Journal of Financial Economics, 71, pp. 517-540.

Ikenberry, D., J. Lakonishok and T. Vermaelen (1995), 'Market Under Reaction to Open Market Share Repurchases,' Journal of Financial Economics, 39, pp. 181-208.

Jung, K., Y.C. Kim and R.M. Stulz (1996), 'Timing, Investment Opportunities, Managerial Discretion, and Security Issue Decision,' Journal of Financial Economics, 42, pp. 159-185.

Kayhan, A. and S. Titman (2007), 'Firms' Histories and Their Capital Structure,' Journal of Financial Economics, 83, pp. 1-32.

Korajczyk, R., D. Lucas and R. McDonald (1991), 'The Effects of Information Releases on the Pricing and Timing of Equity Issues,' Review of Financial Studies, 4, pp. 685-708.

Loughran, T. and J. Ritter (1995), 'The New Issues Puzzle,' Journal of Finance, 50(1), pp. $23-51$.

Loughran, T. and J. Ritter (1997), 'The Operating Performance of Firms Conducting Seasoned Equity Offerings,' Journal of Finance, 52, pp. 1823-1850.

Lucas, D. and R. McDonald (1990), 'Equity Issues and Stock Price Dynamics', Journal of Finance, 45, pp. 1019-1043.

Marsh, P. (1982), 'The Choice Between Equity and Debt: An Empirical Study,' Journal of Finance, 37, pp. 121-144.

Myers, S.C. (1977), 'Determinants of Corporate Borrowing,' Journal of Financial Economics, 5, pp. $147-175$.

Myers, S.C. and N. Majluf (1984), 'Corporate Financing and Investment Decisions When Firms Have Information that Investors Do not Have,' Journal of Financial Economics, 13, pp. 187-221.

Nobes, C. and R. Parker (2000), Comparative International Accounting, 6th edition, Prentice Hall.

Rajan, R.G. and L. Zingales (1995), 'What Do We Know about Capital Structure? Some evidence from International Data,' Journal of Finance, 50, pp. 1421-1460.

Saunders, A. and A. Schmeits (2002), The Role of Bank Funding for the Corporate Sector: The Netherlands in an International Perspective, ACCF Studies no. 5, Amsterdam Center for Corporate Finance, Amsterdam.

Spiess, D. and J. Affleck-Graves (1995), 'Underperformance in Long-run Stock Returns Following Seasoned Equity Offerings,' Journal of Financial Economics, 38, pp. 243-267.

Taggart, R.A. (1977), 'A Model of Corporate Financing Decisions,' Journal of Finance, 43(1), pp. $1-19$.

Titman, S. and R. Wessels (1988), 'The Determinants of Capital Structure Choice,' Journal of Finance, 43, pp. 1-18.

Welch, I. (2004), 'Capital Structure and Stock Returns,' Journal of Political Economy, 112(1), pp. $106-131$. 